\title{
Caesalpinia sappan L. Wood is a Potential Source of Natural Phosphodiesterase-1 Inhibitors
}

\author{
Helmi ' ${ }^{1}$ Nanang Fakhrudin ${ }^{2, *}$, Arief Nurrochmad ${ }^{3}$, Ari Sudarmanto ${ }^{4}$, Zullies Ikawati ${ }^{3}$
}

Helmi ${ }^{1}$, Nanang Fakhrudin ${ }^{2, *}$, Arief Nurrochmad ${ }^{3}$, Ari Sudarmanto ${ }^{4}$, Zullies Ikawati ${ }^{3}$

${ }^{1}$ Faculty of Pharmacy, Universitas Gadjah Mada, Sekip Utara, Yogyakarta 55281 INDONESIA.

${ }^{2}$ Department of Pharmaceutical Biology, Faculty of Pharmacy, Universitas Gadjah Mada, Sekip Utara, Yogyakarta 55281 INDONESIA.

${ }^{3}$ Department of Pharmacology and Clinical Pharmacy, Faculty of Pharmacy, Universitas Gadjah Mada, Sekip Utara, Yogyakarta 55281, INDONESIA.

${ }^{4}$ Department of Pharmaceutical Chemistry, Faculty of Pharmacy, Universitas Gadjah Mada, Sekip Utara, Yogyakarta 55281 INDONESIA.

\section{Correspondence}

\section{Nanang Fakhrudin}

Department of Pharmaceutical Biology, Faculty of Pharmacy, Universitas Gadjah Mada, Sekip Utara, Yogyakarta 55281, INDONESIA.

E-mail: nanangf@ugm.ac.id

History

- Submission Date: 22-05-2020;

- Review completed: 29-06-2020;

- Accepted Date: 06-07-2020.

DOI : 10.5530/pj.2020.12.169

Article Available online http://www.phcogj.com/v12/i6

\section{Copyright}

(C) 2020 Phcogi.Com. This is an openaccess article distributed under the terms of the Creative Commons Attribution 4.0 International license.

\section{ABSTRACT}

Introduction: A decrease in CAMP and CGMP levels in the brain is linked to human cognitive problems. The degradation of cellular CAMP and cGMP is attributed to phosphodiesterases (PDEs), which constitute a superfamily of enzymes. The inhibition of PDE1 is a promising mechanism to increase CAMP and cGMP levels associated with cognitive disorders. Caesalpinia sappan L. (CS) wood is a natural coloring agent usually consumed as a traditional refreshment or drink by people in Yogyakarta, Indonesia. However, scientific evidence regarding the inhibitory activity of CS wood against PDE1 has yet to be obtained. This study aimed to investigate the potency of CS wood as a PDE1 inhibitor. Methods: The ethanol extract of CS wood and its fractions were evaluated in vitro by using a cyclic nucleotide phosphodiesterase assay kit. The presence of brazilin in the extract and fractions was analyzed by thin-layer chromatography. In silico assay was performed using MOE software to obtain insights into the interaction between compounds in the CS wood and the enzyme. Results: Ethanol extract and ethyl acetate soluble fraction effectively inhibited the PDE1 activity. Interestingly, brazilin, the major compound in CS wood, also exhibited a potent inhibitory effect on the enzyme. The in silico assay revealed that the interaction between tetraacetylbrazilin and brazilin with the PDE1B active site involved hydrogen bonding and $\pi-\pi$ interactions. Conclusion: Ethanol extract, ethyl acetate soluble fraction, and brazilin inhibited the PDE1 activity. CS wood and its chemical constituent could be developed as natural cognitive enhancers.

Key words: Brazilin, Caesalpinia sappan L., Phosphodiesterase inhibitor, Herbal cognitive enhancer, Phytotheraphy, Tetraacetylbrazilin.

\section{INTRODUCTION}

Cognitive impairment (CI) is a neurodegenerative disorder that disrupts memory and learning abilities. ${ }^{1,2}$ Memory and learning are important aspects of human cognitive functions regulated by intercellular cyclic nucleotides and cyclic adenosine monophosphate/cyclic guanosine monophosphate (cAMP/cGMP). cAMP/cGMP is a second messenger that plays a key role in the modulation of human neuronal functions. In a clinical context, cAMP/cGMP levels in the brain of patients with CI decrease. ${ }^{3,4}$ The enzyme responsible for the degradation of cAMP/cGMP is phosphodiesterase (PDE). PDE is a superfamily of enzymes grouped into 11 subfamilies (PDE1-PDE11) based on their substrate specificity. Among these subfamilies, PDE1 is the most abundantly expressed in the human brain. ${ }^{5}$

The inhibition of PDE1 causes the upregulation of intercellular cAMP/cGMP levels in the brain. Consequently, cognitive performance increases. ${ }^{5-10}$ These second messengers are required for the expression of brain-derived neurotrophic factor $(\mathrm{BDNF})$ via the protein kinase $\mathrm{A} / \mathrm{G}(\mathrm{PKA} / \mathrm{G})$ cAMP response element binding (CREB) signaling pathway. BDNF is an important protein for the proliferation, differentiation, and plasticity of synapses in the regulation and maintenance of cognitive function, especially learning and memory. ${ }^{11-14}$ PDE1 is a promising molecular target in CI because the inhibition of PDE1 improves cognitive abilities. ${ }^{8,9,15-17}$ Thus, the use of synthetic PDE1 inhibitors (e.g., vinpocetine) effectively increases memory and learning abilities in patients with dementia. Unfortunately, vinpocetine exerts undesirable side effects, such as stomach pain, nausea, sleep disturbances, headache, dizziness, nervousness, and flushing. These effects have become more profound among the elderly. ${ }^{18-20}$ Therefore, the development of PDE1 inhibitors is still a promising approach to combat CI. PDE1 inhibitors may be obtained from medicinal plants because they have been considered a basis for discovering bioactive molecules. ${ }^{6,10,21}$

Secang (Caesalpinia sappan L.; CS) is an Indonesian medicinal plant widely used as a natural red pigment in several herbal medicines. It is also the main ingredient of "Wedang Uwuh," a traditional drink composed of CS wood, clove leaf, and ginger, and it is commonly consumed as a stamina enhancer, body warmer, and refreshment drink. ${ }^{22}$ Previous studies reported that CS wood has antioxidant, antiinflammation, antibacterial, anticancer, antiacne, vasodilator, hepatoprotector, antidiarrheal, aphrodisiac, and antidiabetic activities. ${ }^{23,24}$ However, its cognitive enhancer activity via the inhibition of PDE1 has yet to be scientifically reported. Here, we evaluated the inhibitory activity of CS wood extract, fractions, and brazilin (as the major compound in CS wood) against PDE1 in vitro and predicted their 
molecular interaction in an in silico model. This study contributed to the development of cognitive enhancer agents from natural origins.

\section{MATERIALS AND METHODS}

\section{Plant materials}

CS wood was collected from Imogiri, Bantul, D. I. Yogyakarta, and the plant was authenticated by a botanist at the Department of Pharmaceutical Biology, Faculty of Pharmacy, Universitas Gadjah Mada. The CS wood bark was initially washed and then dried in an oven for $12 \mathrm{~h}$. The dried bark was cut into small pieces and ground using a laboratory grinding mill to produce CS wood powder.

\section{Chemicals}

The following materials were used in this study: cyclic nucleotide phosphodiesterase assay kit (Enzo ${ }^{\star}$ Enzo Life Science, USA; cat. number: BML-AK800); methanol, ethanol, ethyl acetate, chloroform, acetone, and thin-layer chromatography (TLC) silica gel $60 \mathrm{~F}_{254}(20 \mathrm{~cm}$ $\times 20 \mathrm{~cm}$; Merck, Darmstadt, Germany); 3-isobutyl-1-methylxanthine, vinpocetine, formic acid, and Cerium(IV)sulfate $\left(\mathrm{Ce}\left(\mathrm{SO}_{4}\right)_{2}\right.$; Sigma Aldrich, USA); and brazilin (Chengdu Biopurity, China).

\section{CS wood extract and fraction preparation}

CS wood powder $(600 \mathrm{~g})$ was macerated with $600 \mathrm{~mL}$ of ethanol for 24 $\mathrm{h}$ and filtered. The macerate was concentrated using a rotary evaporator (STUART ${ }^{\infty} \mathrm{RE} 300$ ) at $50^{\circ} \mathrm{C}$ and left at room temperature until dryness. The ethanol extract ( $50 \mathrm{~g}$ ) was dissolved with warm destilled water and partitioned with ethyl acetate $(1: 10 \mathrm{v} / \mathrm{v})$ to produce ethyl acetate soluble and insoluble fractions. These fractions were evaporated in a rotary evaporator and left at room temperature until dryness.

\section{Tested solution preparation}

The dried extract and fractions (each $25 \mathrm{mg}$ ) were dissolved in $50 \mathrm{~mL}$ of distilled water and homogenized with an ultrasonic bath (Branson B-220) for $15 \mathrm{~min}$. These solutions were diluted to obtain the final concentration of $500 \mu \mathrm{g} / \mathrm{mL}$ for in vitro assay. Brazilin $(5.2 \mathrm{mg})$ and vinpocetine $(5.0 \mathrm{mg}$ ) were dissolved in $5 \mathrm{~mL}$ of distilled water and diluted to prepare a final concentration of 11.45 and $14.02 \mu \mathrm{g} / \mathrm{mL}$, respectively.

\section{PDE1 inhibition assay}

The PDE1 inhibition assay of the extract and fractions of CS wood were investigated using a cyclic nucleotide phophodiesterase assay kit (ENZO Life Science ${ }^{\oplus}$ BML-AK800). The first mixture to be prepared was composed of $20 \mu \mathrm{L}$ of $0.5 \mathrm{mM} \mathrm{3} 3^{\prime}, 5^{\prime}$-cyclic adenosine monophosphate (cAMP), $10 \mu \mathrm{L}$ of $5 \mathrm{kU} / \mu \mathrm{L} 5^{\prime}$-nucleotidase, $5 \mu \mathrm{L}$ of $10 \mathrm{mM}$ PDE assay buffer, $10 \mu \mathrm{L}$ of $100 \mu \mathrm{g} / \mathrm{mL}$ extract and fraction solution, $11.45 \mu \mathrm{g} / \mathrm{mL}$ brazilin, and $14.02 \mu \mathrm{g} / \mathrm{mL}$ vinpocetine. Then, $5 \mu \mathrm{L}$ of $4 \mathrm{mU} / \mu \mathrm{L}$ PDE1 was added to the first mixture and incubated at $30^{\circ} \mathrm{C}$ for $30 \mathrm{~min}$. Biomol ${ }^{\circ}$ Green Reagent $(100 \mu \mathrm{L})$ was added to terminate the enzymatic reaction. After $30 \mathrm{~min}$ of incubation, absorbance was measured at $620 \mathrm{~nm}$ in a microplate reader (Corona ${ }^{\circ} \mathrm{H}-1000$ ). The serial concentrations of 3, 2 , $1.5,1,0.75,0.5$, and $0.25 \mathrm{nmol} 5^{\prime}$-adenosine monophosphate (5'-AMP) were used to generate a standard curve. An assay buffer was utilized as a negative control. The $5^{\prime}$-AMP level in each experiment was calculated through linear regression obtained from the standard curve of $5^{\prime}$-AMP. The percentage of PDE1 inhibition was calculated with the following formula: $[(\mathrm{A}-\mathrm{B}) / \mathrm{A}] \times 100 \%$, where $\mathrm{A}$ and $\mathrm{B}$ represent the means of $5^{\prime}$-AMP level of the negative control and the tested sample, respectively.

\section{TLC analysis}

The presence of brazilin in the extract and fractions $(10 \mathrm{mg} / \mathrm{mL}$ solution) was analyzed through TLC by using silica gel F254 and chloroform:acetone:formic acid (4:2:0.5 v/v) as stationary and mobile phases, respectively. Compound spots were observed under ultraviolet (UV) light at 254 and $366 \mathrm{~nm}$ and visible light after derivatization by using a Cerium sulfate spray reagent. The presence of the major compound was confirmed with commercially available brazilin (Chengdu Biopurity, China) as a reference compound.

\section{In silico experiment}

A molecular docking experiment was performed with Molecular Operating Environment (MOE) software version 2016.01. A PDE1B isoform (PDB ID: 5W6E) was used with a resolution of $1.90 \AA$. The isoform used as a protein target in this docking experiment was associated with spatial and contextual memory regulatory function in the hippocampus. ${ }^{25}$ Target protein crystals were acquired from Protein Data Bank (RCSB PDB, https://www.rcsb.org/). The 3D structures of 28 tested compounds were obtained from SMILES ID in PubChem (https://www.pubchem.ncbi.nlm.nih.gov/).

\section{Ligand and target protein preparation}

Target proteins were prepared by adding hydrogen atoms, yielding an atomic formal charge, and dispensing water molecules and unnecessary amino acids. Ligands were prepared by minimizing their molecular energy with MMFF94 until the molecular conformation with the lowest energy was obtained.

\section{Molecular docking validation}

Molecular docking was validated by redocking the target protein with its native ligands. PDE1B was docked with PF04677490, a native ligand, in accordance with the following protocol. The ligands were used as the site, induced fit was set as the refinement method, and Alpha PMI and GBVI/WSA dG were used as the algorithm for the scoring function. This process was set at $310 \mathrm{~K}$ and $\mathrm{pH} 7.4$ and run 10 times. The target protein was assumed valid and ready for molecular docking if the RMSD value was $<2 \AA$ and if it had a good protein-ligand complex conformation.

\section{Molecular docking of the tested compounds}

Molecular docking was conducted on 27 compounds previously reported as chemical constituents of CS wood. Vinpocetine, a selective PDE1 inhibitor, was used as a positive control. Docking was conducted in accordance with the protocol from the previous validation. Docking was run at human physiological temperature and $\mathrm{pH}$ to obtain binding free energy ( $\Delta \mathrm{G}$ bind; $\mathrm{kcal} / \mathrm{mol}$ ) as the test parameter in this study.

\section{Statistical analysis}

Data were analyzed through one-way ANOVA and post hoc analysis with Bonferroni tests. Significance level was determined at $p<0.05$ by using IBM SPSS Statistics version 21.

\section{RESULTS AND DISCUSSION}

PDE belongs to a group of hydrolytic enzymes that catalyze the hydrolysis of a phosphodiester bond on $3^{\prime}, 5^{\prime}$-cyclic adenosine monophosphate/3', $5^{\prime}$-cyclic guanosine monophosphate (cAMP/cGMP) into $5^{\prime}$-adenosine monophosphate/5'-guanosine monophosphate (AMP/GMP). This enzyme is important in various physiological functions, including memory function. It is also associated with cognitive disorders in human. PDE1 is highly expressed in the cortex, hippocampus, olfactory bulbs, and brain stem, and these regions participate in the regulation of cognitive functions, such as learning and memory. ${ }^{7}$ Thus, $\mathrm{PDE}$ is a potential target for combating CI.

In this study, the activity of CS wood extract and its fractions was evaluated. Vinpocetine, a selective PDE1 inhibitor derived from Vinca 
rosea alkaloid, was used as a positive control. ${ }^{18}$ The in vitro enzymatic assay revealed that the CS extract and the ethyl acetate soluble fractions elicited a significant inhibitory effect on PDE-1 (Figure 1). No activity was observed in the ethyl acetate insoluble fraction. As expected, vinpocetine showed a potent inhibitory effect on the PDE1 activity, suggesting that this bioassay was sensitive to the presence of PDE1 inhibitor. Interestingly, the inhibitory activity of the extract was stronger (63.48\%) than that of the ethyl acetate soluble fraction (54.78\%) tested at $100 \mu \mathrm{g} / \mathrm{mL}$. A potential synergistic effect might contribute to this activity. ${ }^{26}$ However, further studies might be required to clarify this synergism.

CS wood contains brazilin as a major compound and other various types of compounds, such as flavones, homoisoflavonoids, chalcones, xanthone, and dibenzoxocins. ${ }^{24,27,28}$ In line with previous studies, our phytochemical investigation via TLC analysis found that the CS wood extract and the ethyl acetate soluble fraction also contain brazilin. Brazilin appeared as a brown spot observed under visible light after Cerium(IV)sulfate staining, and the spot has similar color and Rf value with the brazilin reference compound (Figure 2).

The in vitro assay involving brazilin revealed that this compound effectively inhibited the PDE1 activity with the percentage of inhibition of $34.90 \%$ at a concentration of $11.45 \mu \mathrm{g} / \mathrm{mL}$. This result indicated that brazilin is an active compound that might contribute to the inhibitory effect of PDE1.

Previous studies reported that CS wood contains brazilein, brazilide A, tetraacetylbrazilin, brazilane, 3-O-methylbrazilin, neuprotosappanin, protosappanin E1, and hematoxylin..$^{24,28}$ Some of these compounds have structural similarity, so they may be active PDE1 inhibitors as shown by brazilin. Based on that, an in silico approach was applied to predict the interaction between $27 \mathrm{CS}$ wood chemical constituents and PDE1B. In silico approach was conducted using MOE version 2016.01 software. The selected target protein was validated before a molecular docking study was performed. Molecular docking was analyzed using the acquired root mean square deviation (RMSD) values. RMSD is a parameter that represents the reproducibility of a target proteinnative ligand complex in the formation of a suitable and appropriate conformation. An appropriate RMSD value is less than $2 \AA$, but its ideal value is less than $1 \AA$. The superimposition and RMSD value of protein target redocking with its native ligand, PF04677490, is shown in Figure 3. The calculated $\Delta \mathrm{G}$ bind scores of the tested compounds are presented in Table 1.

$\Delta \mathrm{G}$ bind is an important parameter because it represents the receptorligand binding strength between PDE1B and compounds in CS wood. A low $\Delta \mathrm{G}$ bind score also indicates the stability and strength of the interaction between an enzyme (e.g., PDE1B) and its ligands. These factors contribute to the resulting pharmacological effects. In Table 1,22 (compound numbers 2-23) of the 28 tested compounds in CS wood were predicted to inhibit the PDE1B activity. Vinpocetine, as the reference drug, was predicted to interact with the enzyme, with $\Delta \mathrm{G}$ bind of $-5.438 \mathrm{kcal} / \mathrm{mol}$. Among the tested compounds, tetraacetylbrazilin is predicted to have the strongest interaction with PDE1B, whereas protosappanin B has the weakest interaction; they had $\Delta \mathrm{G}$ bind of -8.691 and $-5.498 \mathrm{kcal} / \mathrm{mol}$, respectively. $\Delta \mathrm{G}$ bind of protosappanin $\mathrm{B}$ is equal to that of vinpocetine and almost equal to brazilin, the major compound in CS wood ( $\Delta \mathrm{G}$ bind of $-5.823 \mathrm{kcal} /$ mol). Protosappanin D, protosappanin E1, caesalpin J, caesalpinin P, and 2,4,5-trihydroxybenzaldehyde were predicted as inactive because they demonstrated $\Delta \mathrm{G}$ bind lower than that of vinpocetine $(-5.438$ $\mathrm{kcal} / \mathrm{mol}$ ). The interaction of tetraacetylbrazilin and brazilin with PDE1B is illustrated in Figure 4.

In Figure 4, tetraacetylbrazilin showed two $\pi-\pi$ interactions with the enzyme; that is, their interaction involves the benzene rings of

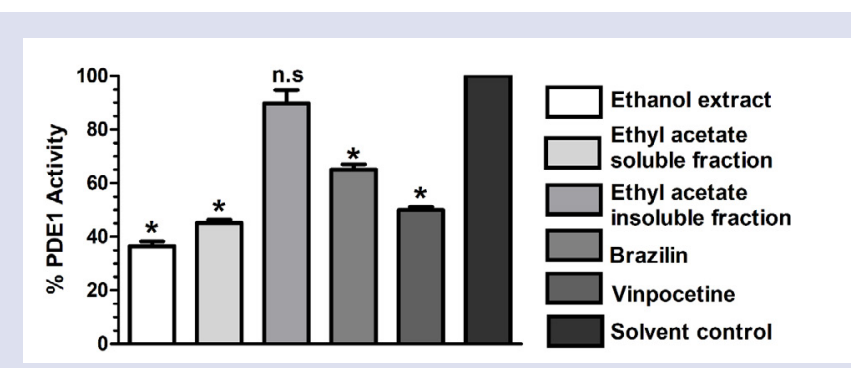

Figure 1: Inhibitory activity of the CS extract, fractions, and brazilin against PDE1. The assay was conducted using a PDE1 inhibition assay kit (cyclic nucleotide phosphodiesterase assay kit). The extract and the fractions were tested at $100 \mu \mathrm{g} / \mathrm{ml}$, whereas brazilin was examined at 40 $\mu \mathrm{M}$ or $11.45 \mu \mathrm{g} / \mathrm{mL}$. Data were analyzed with one-way ANOVA followed by Bonferroni post hoc test. Data were presented as mean \pm SEM $\left({ }^{*} p<\right.$ $0.05 ; \mathrm{n} . \mathrm{s}$ : not significant compared with the solvent control).

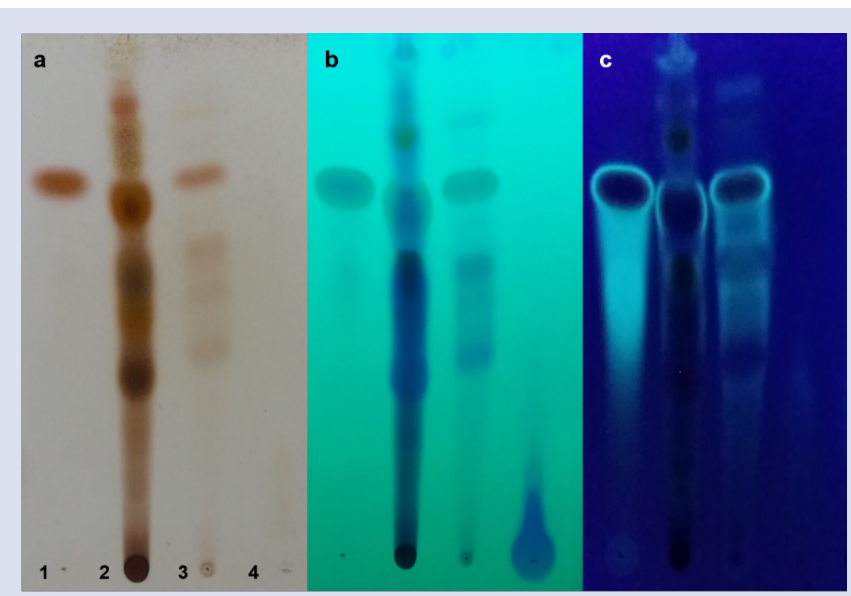

Figure 2: TLC profile of the extract, fractions, and brazilin. (1) Brazilin (2) ethanol extract of CS wood, (3) ethyl acetate soluble fraction, and (4) ethyl acetate insoluble fraction. TLC was conducted on a stationary phase of silica gel $F_{254}$ by using the mobile phase of chloroformacetone:formic acid (4:2:0.5 v/v). The TLC plate was visualized under visible light after it was sprayed with Cerium sulfate (a) and exposed to UV light at 254 (b) and $366 \mathrm{~nm}$ (c).

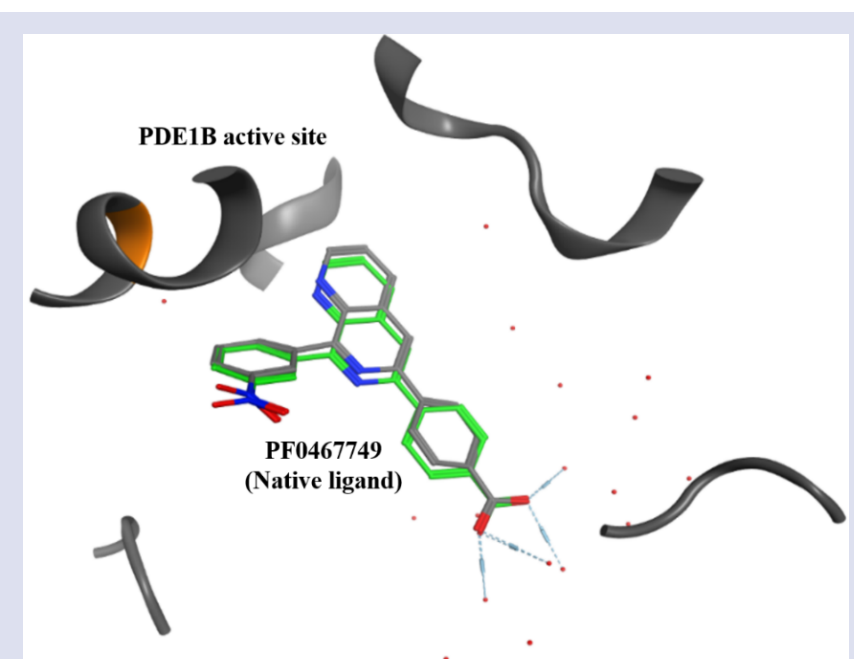

Figure 3: Superimposition of the redocked PF0467749, the native ligand compound of PDE1B. The poses show an overlapping or a similar interaction before (green) and after (grey) redocking with amino acid residues on the PDE1B active site. The RMSD score was $0.27 \AA \AA(<1 \AA$; PDB ID: 5W6E). 


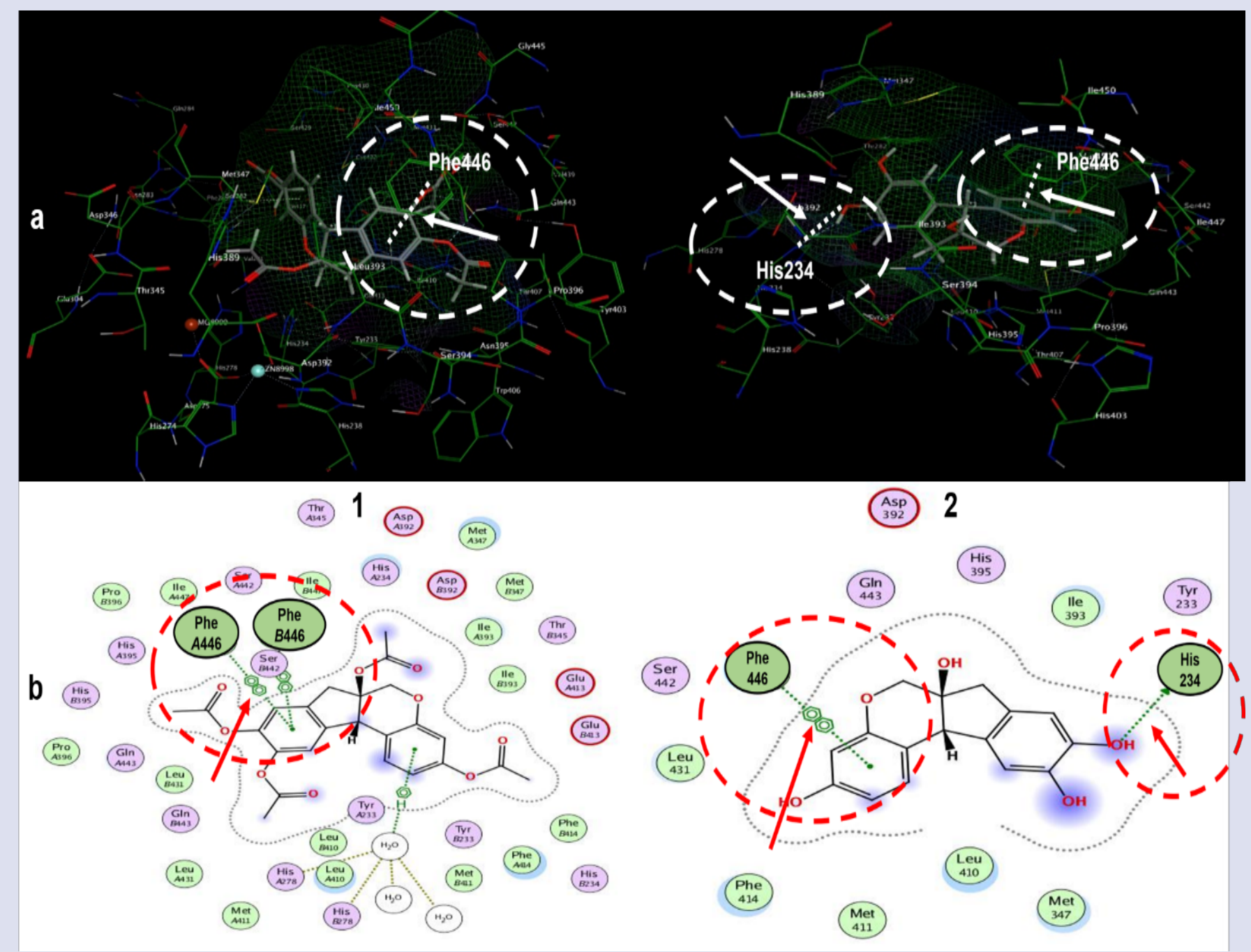

Figure 4: Interaction of tetraacetylbrazilin (1) and brazilin (2) with amino acid residues on the PDE1B active site. The interaction is illustrated in 3D (a) and 2D (b) models by using MOE ver. 2016.01.

Table 1: Binding free energy ( $\Delta \mathrm{G}$ bind) scores of compounds in CS wood (2-28) and vinpocetine as a positive control (1). Numbers 2-28 correspond to the strength of the interaction between PDE1B and the respective compound.

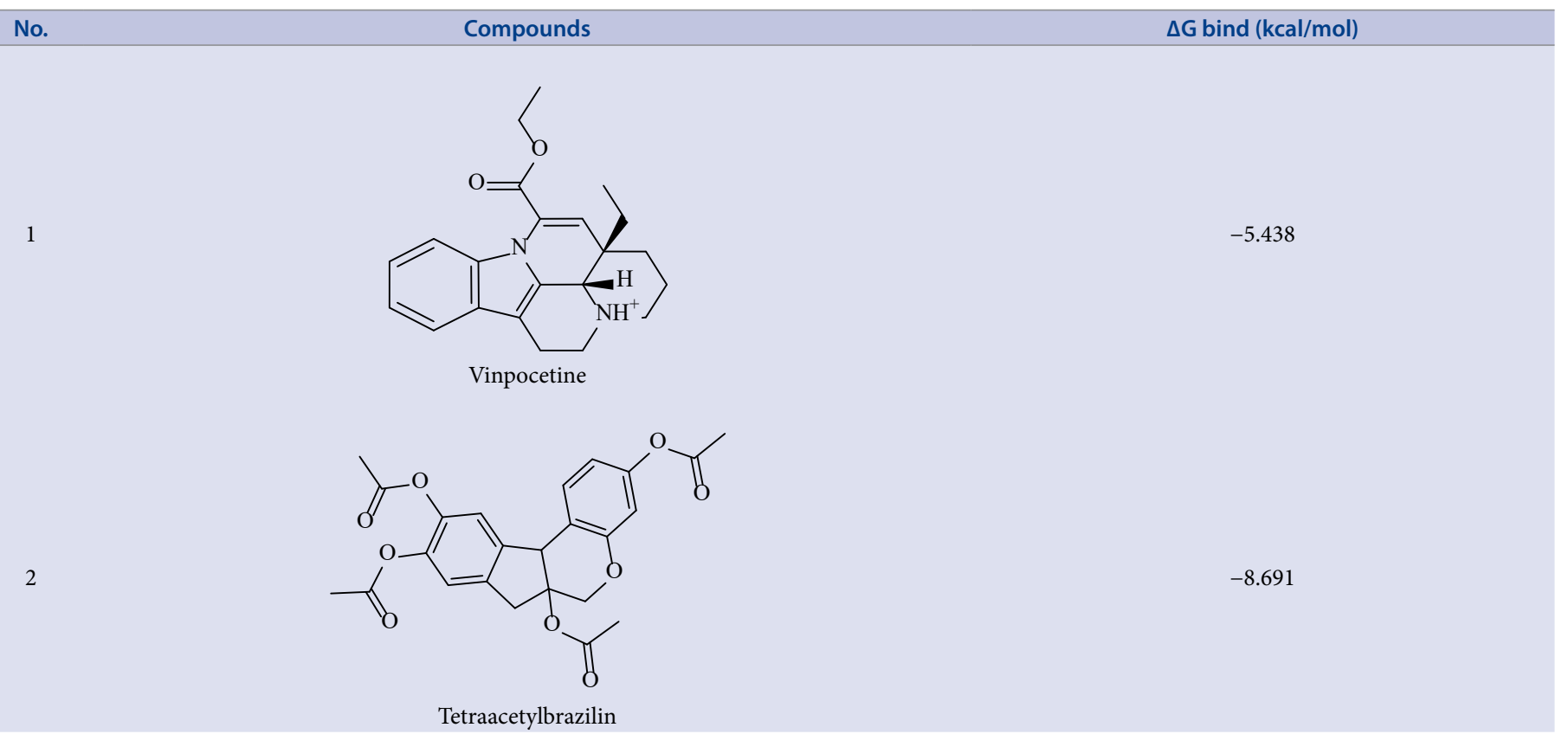


3<smiles>O=C1c2ccc(O)cc2OC[C@]1(O)Cc1ccc(O)c(O)c1</smiles><smiles>N#Cc1cc(O)c(O)cc1[C@H]1c2cc([C@@H]3c4cc(O)c(O)cc4[C@@H]4c5ccc(O)cc5OC[C@]34O)c(O)cc2OCC1(O)O</smiles><smiles>COc1cc(O)ccc1C(=O)/C=C/c1ccc(O)cc1</smiles><smiles>O=C1c2ccc(O)cc2OCC1Cc1ccc(O)c(O)c1</smiles>

3-Deoxysappanone B<smiles>O=C(/C=C/c1ccc(O)c(O)c1)c1ccc(O)cc1O</smiles><smiles>COc1cc(O)ccc1C(=O)/C=C/c1ccc(O)c(O)c1</smiles> 
9<smiles>COc1cc2c(cc1O)[C@H]1c3ccc(O)cc3OC[C@]1(O)C2</smiles>

10<smiles>O=C1/C(=C/c2cc(O)c(O)c(O)c2O)COc2cc(O)ccc21</smiles>

Caesalpiniaphenol G<smiles>O=C1/C(=C/c2ccc(O)c(O)c2)COc2cc(O)ccc21</smiles>

Sappanon A<smiles>Oc1ccc2c(c1)OC[C@](O)(Cc1ccc(O)c(O)c1)[C@H]2O</smiles>

13<smiles>C[C@]12CC3(O)COc4cc(O)ccc4C3[C@@]13OC(=O)[C@H]3C(=O)O2</smiles><smiles>Oc1ccc2c(c1)OCCCc1cc(O)c(O)cc1-2</smiles> 
<smiles></smiles>

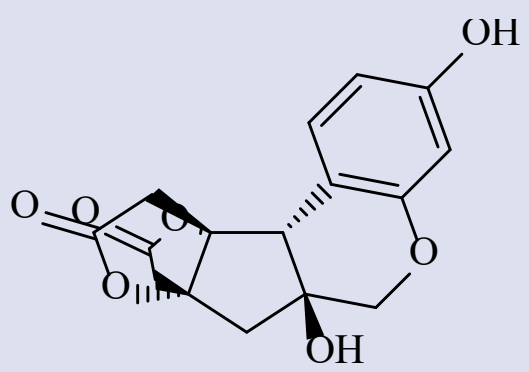

Brazilide A<smiles>Oc1ccc2c(c1)OCC1(O)Cc3cc(O)c(O)cc3C21</smiles><smiles>O=c1oc2cc(O)ccc2c2cc(O)c(O)cc12</smiles>

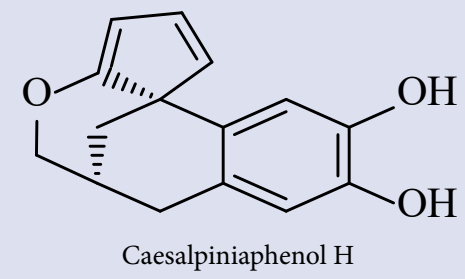


20<smiles>Oc1cc2c(cc1O)C1c3ccc(O)c(O)c3OCC1(O)C2</smiles>

21<smiles>O=C[C@]1(O)COc2cc(O)ccc2-c2cc(O)c(O)cc2C1</smiles><smiles>O=c1c2cc(O)ccc2oc2cccc(O)c12</smiles>

Euxanthone

23<smiles>OC[C@]1(O)COc2cc(O)ccc2-c2cc(O)c(O)cc2C1</smiles>

24<smiles>Oc1ccc2c(c1)OC[C@H]1OC(O)[C@H]3COc4cc(O)ccc4-c4cc(O)c(O)cc4[C@@H]3C(O)O[C@H]1c1cc(O)c(O)cc1-2</smiles>

Protosappanin D 


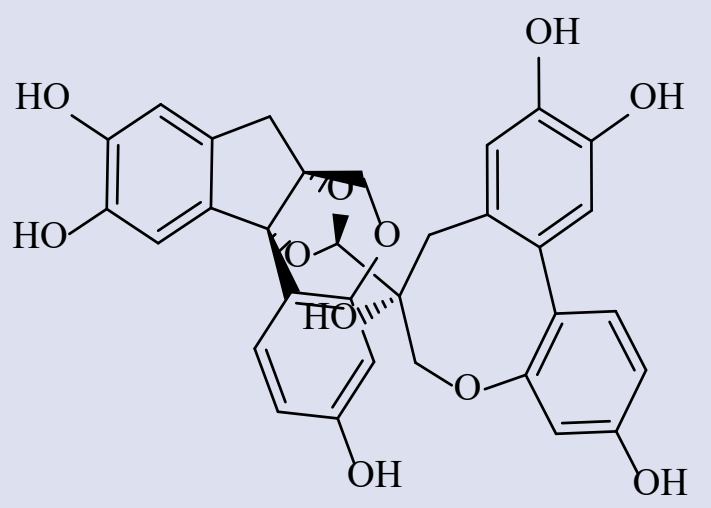<smiles>COC1C2(O)COC3=CC(=O)C=CC31c1cc(O)c(O)cc1C2</smiles><smiles>O=Cc1cc(O)c(O)cc1O</smiles><smiles>C=C1c2ccoc2C[C@H]2[C@@H]1CC[C@@]1(O)[C@]2(C)[C@H](OC(C)=O)[C@@H](OC(C)=O)C[C@@]1(C)O</smiles>

tetraacetylbrazilin and the two benzene rings of phenylalanine-A446 (PheA446) and phenylalanine-B446 (PheB446) residues of the enzyme with a similar bond length of $3.66 \AA$. Interestingly, brazilin showed two distinct chemical interactions with the PDE1B active site. In particular, a $\pi-\pi$ interaction occurs between the benzene ring of brazilin and the benzene ring of the Phe446 with a bond length of $3.66 \AA$, and a hydrogen donor interaction takes place between the hydroxyl group (O-23) and the nitrogen of histidin-234 (His234) residue with a bond length of $3.18 \AA$. This interaction is consistent with a previous study. ${ }^{29}$ Our in silico study showed that at least 22 constituent compounds of CS wood extract might interact with PDE1, as indicated by low $\Delta \mathrm{G}$ bind scores docked with PDE1B. This finding suggested that the PDE1 inhibitory activity of CS wood extract might be related to the synergistic effect of its constituent involving at least 22 compounds. However, their effectiveness in synergism must be confirmed in relevant bioassays. These findings indicated that CS wood could be a potential source of a natural cognitive enhancer agent for combating memory disorders.

\section{CONCLUSION}

In this study, CS wood extract, ethyl acetate fractions, and brazilin as the major compound of CS wood inhibited the PDE1 activity in the enzymatic in vitro assay. However, the activity of the extract was stronger than that of the fraction. Our in silico approach revealed that PDE1B interacted with at least 22 constituents of CS wood. 


\section{ACKNOWLEDGMENT}

The authors would like to express their gratitude to the Ministry of Research, Technology, and Higher Education (KEMENRISTEKDIKTI) through the scholarship of the Program Magister menuju Doktor untuk Sarjana Unggul (PMDSU) with the contract number 3167/UN1. DITLIT/DIT-LIT/LT/2020 for the financial support during the research and preparation of this manuscript.

\section{REFERENCES}

1. Forlenza OV, Diniz BS, Stella F, Teixeira AL, GattazWF. Mild cognitive impairment. Part 1: clinical characteristics and predictors of dementia. Rev Bras Psiquiatr. 2013;35:178-85.

2. Mufson EJ, Lester B, Scott EC, Steven TD, Leyla DTM, Stephen DG, et al. Mild Cognitive Impairment: Pathology and mechanisms. Acta Neuropathol. 2012;123:13-30.

3. Hesse R, Ludwig L, Pauline G, Florian S, Anke W, Cathrin, S, et al. Reduced cGMP levels in CSF of AD patients correlate with severity of dementia and current depression. Alzheimers Res Ther. 2017;9(1):17.

4. Oeckl P, Petra S, Stefan L, Sarah J, Hans AK, Albert CL, et al. CSF Concentrations of CAMP and CGMP Are Lower in Patients with Creutzfeldt-Jakob Disease but Not Parkinson's Disease and Amyotrophic Lateral Sclerosis. PLOS ONE. 2012;7(3):e32664.

5. Wu Y, Li Z, Huang YY, Wu D, Luo HB. Novel Phosphodiesterase Inhibitors for Cognitive Improvement in Alzheimer's Disease: Miniperspective. Journal of Medicinal Chemistry. 2018;61:5467-83.

6. Kumar A, Vishavdeep S, Vijay PS, Madhu K, Manish KG, Jitender B, et al. Herbs to curb cyclic nucleotide phosphodiesterase and their potential role in Alzheimer's disease. Mechanisms of Ageing and Development. 2015;149:7587.

7. Conti M, Richter W. Phosphodiesterases and Cyclic Nucleotide Signaling in The CNS. In: Brandon, N. J., West, A. R., Editors. Cyclic-Nucleotide Phosphodiesterases in The Central Nervous System. John Wiley \& Sons, Inc, p. 1-46; 2014

8. Froestl W, Muhs A, Pfeifer A. Cognitive Enhancers (Nootropics). Part 2: Drugs Interacting with Enzymes. Update 2014. Journal of Alzheimer's Disease. 2014;42:1-68.

9. Patel DS, Anand IS, Bhatt PA. Physiological Activity of Phosphodiesterase. Research Journal of Pharmacology and Pharmacodynamics. 2011;3:223-33.

10. Rahimi R, Ghiasi S, Azimi H, Fakhari S, Abdollahi M. A review of the herbal phosphodiesterase inhibitors; Future perspective of new drugs. Cytokine. 2010;49:123-9

11. Alberini CM. Transcription Factors in Long-Term Memory and Synaptic Plasticity. Physiological Reviews. 2009;89:121-45.

12. Saavedra A, Giralt A, Arumí H, Alberch J, Pérez-Navarro E. Regulation of Hippocampal cGMP Levels as a Candidate to Treat Cognitive Deficits in Huntington's Disease. PLOS ONE. 2013;8(9):e73664.
13. Nair A, Vaidya VA. Cyclic AMP response element binding protein and brainderived neurotrophic factor: Molecules that modulate our mood? Journal of Biosciences. 2006;31:423-34.

14. Keravis T, Lugnier C. Cyclic nucleotide phosphodiesterase (PDE) isozymes as targets of the intracellular signalling network: benefits of PDE inhibitors in various diseases and perspectives for future therapeutic developments: PDEs: intracellular network targets for diseases. British Journal of Pharmacology 2012;165:1288.

15. Blokland A, Menniti FS, Prickaerts J. PDE Inhibition and cognition enhancement Expert Opinion on Therapeutic Patents. 2012;22:349-54.

16. Omori K, Kotera J. Overview of PDEs and Their Regulation. Circulation Research. 2007;100:309-27.

17. Medina AE. Therapeutic Utility of Phosphodiesterase Type I Inhibitors in Neurological Conditions. Frontiers in Neuroscience. 2011;5.

18. Szatmari SZ, Whitehouse PJ. Vinpocetine for cognitive impairment and dementia. Cochrane Database Syst Rev. 2003;1:CD003119.

19. Ogunrin A. Effect of Vinpocetine (Cognitol ${ }^{\top M}$ ) on Cognitive Performances of a Nigerian Population. Ann Med Health Sci Res. 2014;4:654-61.

20. 2Khulbe P, Vijay J. Vinpocetine: A Step Towards Memory Enhancement. Inter J Pharm Res Dev. 2013;2(12):99-108.

21. Achilonu MC, Umesiobi DO. Bioactive Phytochemicals: Bioactivity, Sources, Preparations, and/or Modifications via Silver Tetrafluoroborate Mediation. Journal of Chemistry. 2015:1-22.

22. Rahmawati F. Kajian Potensi "Wedang Uwuh" sebagai Minuman Funsional Seminar Nasional Wonderful Indonesia. 2011;12.

23. Rina O. Stabilities natural colorant of Sappan wood (Caesalpinia sappan L.) for food and beverages in various $\mathrm{pH}$, temperature, and matrices of food. International Journal of ChemTech Research. 2017;6.

24. Nirmal NP, Rajput MS, Prasad RGSV, Ahmad M. Brazilin from Caesalpinia sappan heartwood and its pharmacological activities: A review. Asian Pacific Journal of Tropical Medicine. 2015;8:421-30.

25. McQuown S, Shouzhen X, Karsten B, Richard B, Gary A, Brian D, et al. Phosphodiesterase 1B (PDE1B) Regulates Spatial and Contextual Memory in Hippocampus. Front Mol Neurosci. 2019;12(21).

26. Yuan H. How Can Synergism of Traditional Medicines Benefit from Network Pharmacology? Molecules. 2017;22(1135).

27. Nirmal NP, Panichayupakaranant P. Antioxidant, antibacterial, and antiinflammatory activities of standardized brazilin-rich Caesalpinia sappan extract. Pharmaceutical Biology. 2015;53:1339-43.

28. Wagner H, Bauer R, Melchart D, Staudinger A, Editors. Chromatographic Fingerprint Analysis of Herbal Medicines: Thin-Layer and High-Performance Liquid Chromatography of Chinese Drugs Volume 4. Springer; 2016.

29. Helmi Nanang F, Arief N, Arie S, Zullies I. In Vitro and In Silico Studies of Secang Wood (Caesalpinia Sappan L.) Extracts and Brazilin as Natural Phosphodiesterase-1 (PDE1) Inhibitor for Herbal Cognitive Enhancer Development. Res J Pharm Tech. 2020;13(5). 


\section{GRAPHICAL ABSTRACT}

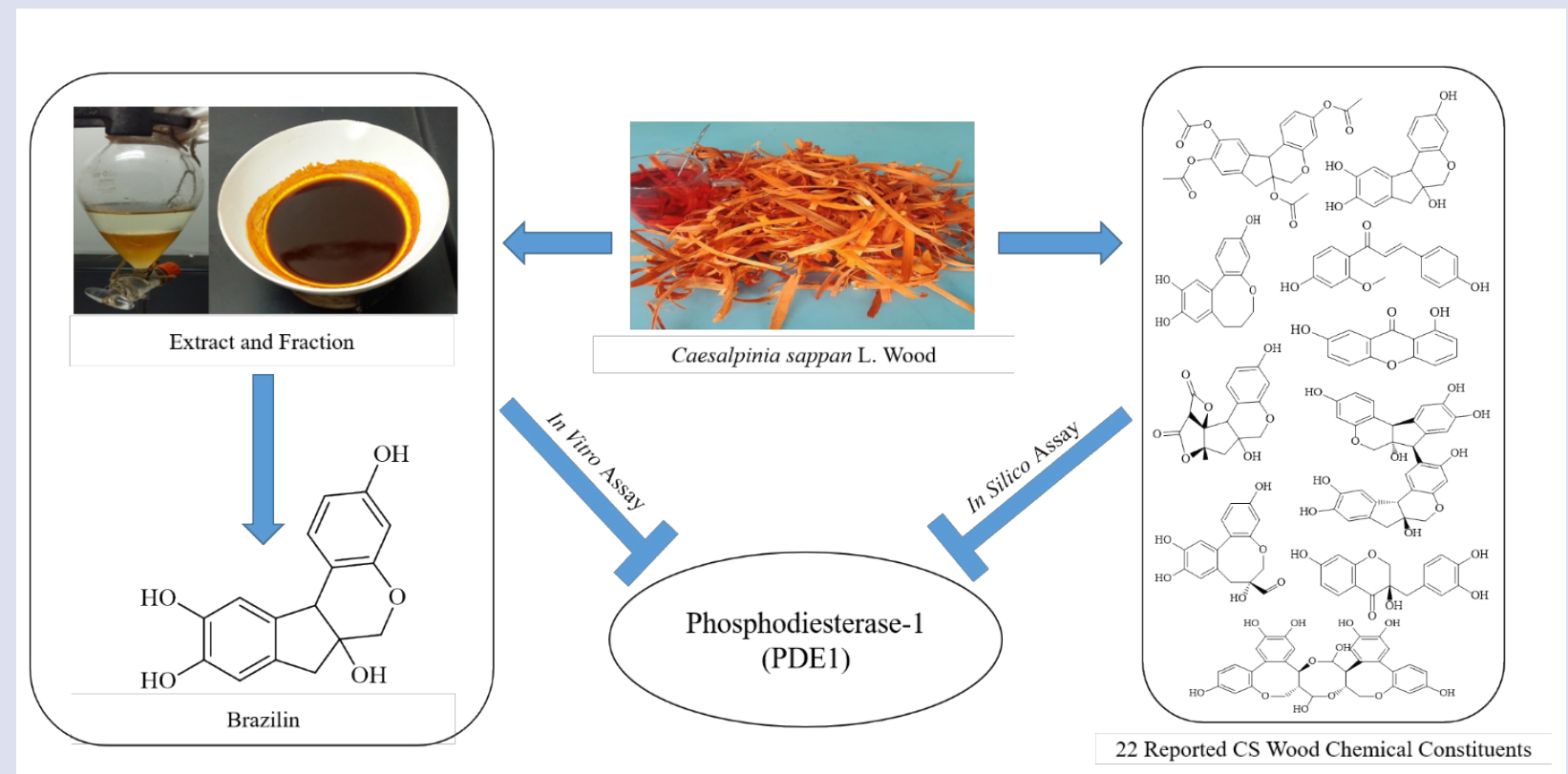

\section{ABOUT AUTHORS}

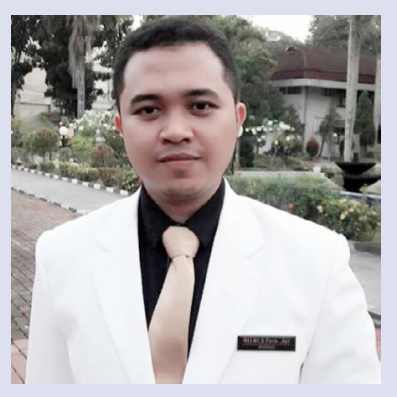

apt. Helmi, S.Farm.

apt. Helmi, S.Farm. is a Ph.D Candidate at the Doctoral Degree Program in the Pharmaceutical Science-Technology, Faculty of Pharmacy, Universitas Gadjah Mada. His graduate research is on herbal medicines for cognitive enhancer.

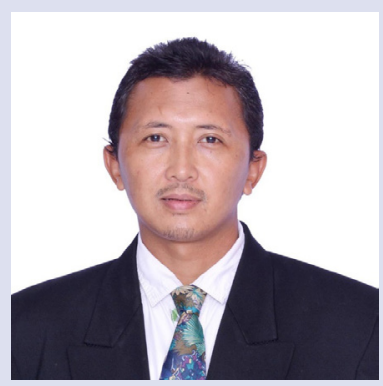

\section{Dr.rer.nat. apt. Nanang Fakhrudin, M.Si.}

Dr.rer.nat. apt. Nanang Fakhrudin, M.Si. is a lecturer and researcher at Department of Pharmaceutical Biology, Faculty of Pharmacy, Universitas Gadjah Mada. He is doing researches in phytochemistry and biological activities of medicinal plants and bioactive compounds, including bioactivites screening.

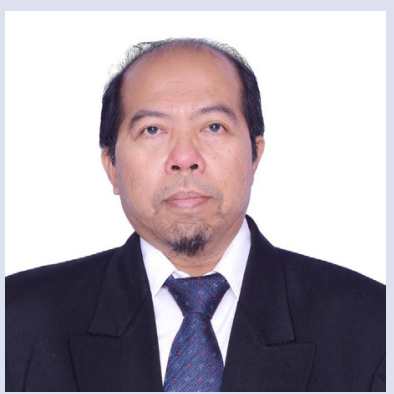

\section{Dr. apt. Arief Nurrochmad, M.Si., M.Sc.}

Dr. apt. Arief Nurrochmad, M.Si., M.Sc. is a lecturer and researcher at Department of Pharmacology and Clinical Pharmacy, Faculty of Pharmacy, Universitas Gadjah Mada. He is actively doing researches in pharmacology and toxicology. His research interest are clinical toxicology, molecular pharmacology and toxicology, neuropharmacology and pharamcotherapy of degenerative disease. His invention in derivatives of benzylidene cyclohexanone, benzylidene cyclopentanone and benzylidene acetone and therapeutic uses thereof was granted as US patent in 2004. 

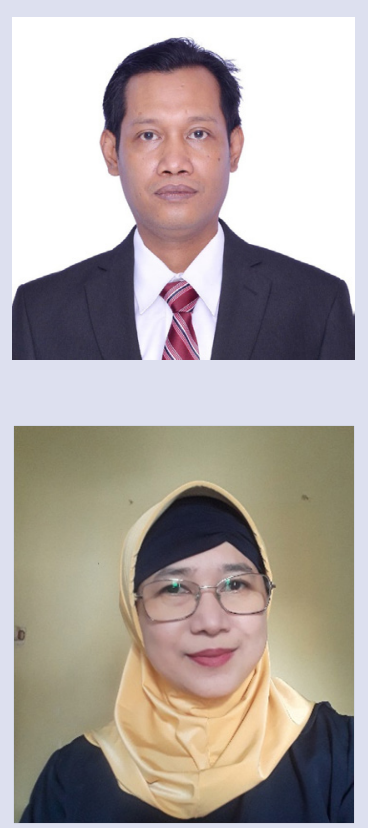

\section{Dr. B. S. Ari Sudarmanto, M.Si.}

Dr. B. S. Ari Sudarmanto, M.Si. is a lecturer and researcher at the Department of Pharmaceutical Chemistry, Faculty of Pharmacy, Universitas Gadjah Mada. His major expertize is in pharmaceutical chemistry with the research of interest in computational chemistry and medicinal chemistry.

\section{Prof. Dr. apt. Zullies Ikawati}

Prof. Zullies Ikawati, PhD, Pharm is academician with specialization in Pharmacology and Clinical Pharmacy in Faculty of Pharmacy Universitas Gadjah Mada. She earned PhD degree in Pharmacology from Ehime University Japan in 2001. She is actively doing research in the field of pharmacology, clinical pharmacy, and pharmacogenomics. She conducted several clinical trials of herbal medicine products for several indication, such as diabetes mellitus, hyperlipidemia, and common cold. She has published many articles in international journals, with interest of pharmacology, clinical pharmacy and pharmacogenomics.

Cite this article: Helmi, Fakhrudin N, Nurrochmad A, Sudarmanto A, Ikawati Z. Caesalpinia sappan L. Wood is a Potential Source of Natural Phosphodiesterase-1 Inhibitors. Pharmacogn J. 2020;12(6): 1206-17. 